\title{
The Use of Reflection-for-Action in Planning English Language Lesson at Primary School
}

\author{
Siti Noor Ane eis Hashim ${ }^{1, *}$, Nurahimah Mohd Yusoff ${ }^{2}$ \\ School of Education and Modern Languages, Universiti Utara Malaysia, Malaysia \\ Received January 22, 2020; Revised March 2, 2020; Accepted March 12, 2020
}

Copyright $\odot 2020$ by authors, all rights reserved. Authors agree that this article remains permanently open access under the terms of the Creative Commons Attribution License 4.0 International License

\begin{abstract}
Teaching English language is a challenging task for primary school teachers. Teachers need to plan their lesson to match all levels of students in one class as there is no streaming classes allowed. This study explored how reflection-for-action to be used by the English language teachers at primary schools in Northern state of Peninsular Malaysia in planning their teaching starting from choosing lesson objectives, planning the activities and preparing the materials. Hence, this study also gathered another relevance data on principles, benefits, changes and stages of reflection which led the teachers to use reflection-before-action in teaching English language. There were six participants involved in this study, three of them were male. The participants were experienced teachers who teach English language at primary schools with more than eighteen years teaching experience. This study used semi-structured interviews to collect the data. The researchers used thematic analys is to analyze the data. The findings revealed that reflection-for-action was very helpful to help the teachers to plan a meaningful lesson, to improve their teaching and to maximize their students' learning and knowledge of the target language. After applying reflection-for-action, the English language teachers managed to plan specific teaching activities to deliver specific skills in English language classroom to suit their teaching and learning contexts. Therefore, the four main themes found in this study contribute a recommendation for the teachers to learn and to use reflection-for-action dynamically to plan a meaningful lesson for multiple intelligence students in the classroom. Hence, the findings also found that teachers need to apply theory in practice to plan and reason their lesson plan arrangements to fulfil the nature of teaching and learning process which needs them to attain the skills, objectives, knowledge, experiences, subject to be taught and the materials to be learned in the current teaching and learning context.
\end{abstract}

Keywords Reflection-for-Action, Lesson Planning,
English Language, Primary School

\section{Introduction}

Reflective practice is important for every teacher at schools to reflect on their classroom experiences and to learn from it [37]. Through reflective practice, teachers could think critically [12] and they manage to use their implic it knowledge to solve the problems occurred in their classroom [18]. Besides that, reflective practice allows teachers to observe, evaluate and response to their past experiences which involves conscious recall and examination to make a better decision to plan their lesson and to take a better action for future teaching [27] [39].

\subsection{Reflection-for-Action}

Teachers commonly use reflective practice to evaluate their own teaching in three phases which are known as reflection before teaching, reflection while teaching and reflection after teaching at schools to gain new insights of self and practice [23]. The three phases are also described as reflection-in-action, reflection-on-action and reflection-for-action [23].

Through reflection-in-action and reflection-on-action phases, the teachers are able to gather the information to get new insights about their own teaching [15][16]. By linking the theories and their practices in these phases [28], the teachers manage to draw their in-depth knowledge of their own pedagogical practices to improve their own performance and professionalism during reflection-for-action phase [4], [10], [32], [40].

In line with that, they are able to use the input from reflection-for-action phase to plan a better lesson, to prepare suitable learning materials to fulfil their students' needs, to solve the dilemma they faced in the classrooms 
[32],[36]. Besides that, the teachers manage to make changes to meet their students' need and the pedagogical needs in order to teach effectively [16], [2].

Regarding that, the use of reflection-for-action in planning a lesson is important for the teachers to make sure they are well-prepared to deliver the right things to the students in the classrooms [5]. Well-prepared teachers also inspired students learning [35] as reflective teachers manage to teach well by supporting their students' strengths and needs to engage their students in ambitious learning environment [14]. Besides that, the use of reflection-for-action yield the opportunities and possibilities to the teachers to reflect and grant those successful experiences to have ideas to reframe and make adjustment in their instructions to plan effective lesson by considering the strengths and weaknesses in their previous lessons to improve students' knowledge of the target language [11].

\subsection{The Benefits of Reflection-for-Action in Planning a Lesson}

Planning a lesson is an importance stage for teachers to plan their lesson to provide opportunities for every student to learn on their own pace [1]. Based on the combination of their previous experiences at reflection-for-action phase or planning stage, they manage to reflect and learn from it to get new insights which allow them to use their empirical evidence as their source of reference to plan their lesson and to improve their teaching [16]. By concerning on the success or unsuccess in the choices of materials and approaches made during planning their lesson, they could determine the patterns of variation and provide suitable classroom environment to suit their students and their teaching context [34]. As a result, they are able to make their students to understand the content more easily and successfully achieved the knowledge of the target language through their own experiences, previous research and prior knowledge [31].

Regarding that, [23] and [16] suggested the teachers to reflect before planning the les son to plan a comprehensive lesson. According to [22], the decision making process during reflection-for-action phase gives the guidelines to the teachers to plan their teaching meaningfully by concerning on the examples and variation from the previous lesson and the requirement on the new lesson to help their students to understand what they should learn and what they should do to learn meaningfully.

Similarly, [21], also found that the correct selection of strategies during planning stage enable the teachers to elic it appropriate cognitive processes to improve instructional delivery. [20] also found that it will encourage the students' understanding of rote me morization and it will facilitate the students' cognitive engagement process to encode the content of the target language to be learned through mean ingful activities planned which relate the new input to students' existing knowledge. In line with that, planning a lesson requires the teachers to reflect and become more conscious of their own actions and choices made to make sure their students manage to process the knowledge of the target language taught in the clas srooms [31].

Therefore, the use of reflection-for-action in teaching will help English Language teachers to think and choose a variety of techniques, learning theories and instructional design models which provide the foundation for the teachers to select suitable and effective instructional strategies [41]. Besides that, by implementing reflection-for-action, teachers are able to face the challenges on the current conceptions of teaching and learning by making changes in future lesson through decision-making during reflection-for-action phase [37].

\subsection{Current Study}

There have been many quantitative and qualitative studies on reflective practices. But there is little research or studies on in-service English language teachers' reflective practice at primary schools. Most of the previous studies in the education field whose findings have been infused with enthusiasm on the part of trainee teachers, student teachers or pre-service teachers and lecturers in favour of reflective approaches.

To better prepare in-service teachers to face the challenges in the current education demands and to teach the diverse groups of students, the teachers need to use frameworks or models for them to nurture and foster the quality of reflection-for-action to plan their teaching [24].

Similar to that [17], [3], found that teachers need support and collaboration to help them to use reflect-for-action effectively by considering their reflection-in-action and reflection-on-action process to help them to plan and make changes in their teaching. Therefore, [25], [42], [26] as well as [19] also agreed with the above findings that in-service teachers also need to know how to use reflection-for-action to plan a better lesson.

1. This study is carried out to fulfil the gap by exploring the use of reflection-for-action among in-service English language teachers during planning their lesson. This study seeks to answer how English Language teachers use reflection-for-action to plan a lesson.

\section{Materials and Method}

\subsection{Participants}

Six participants were involved in this study, three of them were male. They were between 40 to 50 years old. All participants were graduates in English Language from local universities. The participants were excellent teachers who have experience of more than 15 years in teaching 
English language at primary schools. The participants were selected based on purposive sampling criteria. They had experiences in using and implementing reflection in their teaching. They also had experiences in using reflective teaching and doing reflective activities in their classrooms. All participants completed an informed consent. They voluntarily participated in this study after reading and understanding the terms and condition stated in the informed consent.

\subsection{Materials}

This study used open-ended interview, teachers' lesson plans and teachers' post lesson reflections to collect the data. The interviews were using specific interview protocols to get the valid data and to avoid bias. The interview transcripts, teachers' less on plans and teachers' post less on reflections were used in th is study to triangulate the data.

The participants completed the interviews in three phases. The researcher transcribed the interviews in verbatim. To avoid bias in collecting the data, the researcher collected and analysed teachers' lesson plans and triangulated the data between interview transcripts and post lesson reflections. The researcher used [16] Farrell'S three stages reflection model to plan a lesson to answer research question 1 (see Appendix 1). The three stages are forward planning stage, central planning stage and backward planning stage which is related to reflection-for-action activities. The researcher conducted a qualitative analysis by using thematic analysis to analyse the interview transcripts, teachers' lesson plans and teachers' post lesson reflections to report the findings.

\section{Results and Discussions}

The results from the interviews, teachers' lesson plans and teachers' post lesson reflections portrayed that the teachers were reflected before teaching. The find ings from Phase one interview revealed the reasons to do reflection-for-action. The second phase interview highlighted the reflection-for-action. The third phase interview showed the changes the teachers made from reflection-for-action. Meanwhile, the fourth phase exposed the extent of reflection-for-action done by the teachers.

\subsection{Theme One: The Issues to Do Reflection-for-Action}

The participants claimed that they reflected before teaching by concerning on the problematic activities, the critical incidents happening in the classroom, the changes and adjustments they made in some of the activities. They mostly reflected on their students' participation in the activities by concerning the gestures and expressions shown by the students in order to assist them to organize their knowledge logically.
Sub-theme: Reflecing before teaching by concerning the problematic activities

"I will not do the similar activities as previous as the students tend to behave badly when they could not accept the failure they got during group activities as they tend to blame others" (Interview 1, Teacher 3, $2^{\text {nd }}$ June 2019).

Sub-theme: Reflecting before teaching by concerning the critical incidents happening in the clas sroom.

"It is good to learn from what I've been through, as for example I won't use or take the examples which might relate to my students' bad experiences. I experienced it when I was writing in class where one of them screaming and crying badly and I found out that she had bad experience in losing her way in the shopping mall" (Interview 1, Teacher 4, $15^{\text {th }}$ June 2019).

Sub-theme: Reflecting before teaching by concerning negative gestures and expressions shown by the students

"I did some changes if the students seem to show bad gestures, bored faces, confuse faces and sleepy in my class. For example, in my lesson plan I plan to do chain reading literally, inferentially and evaluate meaning but my students showed sleepy faces and yawn frequently, definitely I am not continuing with it, I rather change the activity by making café reading to promote cooperative work to talk to read, to tell and to understand the text using their own words with friends as to assist them to organize their knowledge logically." (Interview 1, Teacher 2, $21^{\text {st }}$ June 2019)

\subsection{Theme Two: The Compensations to Do Reflection-for-Action}

They also claimed that their reflection before teaching by referring to the previous lessons experiences helped to counterbalance their less on planning based on the strengths and weaknesses they found in the lesson. They use the outcomes to enhance the quality of their teaching and to increase their students' performance by not repeating the same disappointments in their teaching. The changes of the approaches, techniques, materials and the activities used can be seen in their lesson plans.

Sub-theme: Making new plan to maximize students learning

"Reflecting on the previous experiences allow me to make changes in my plan. Normally, I will skip or pick the most important and successful parts of the previous plan to work on the new lesson plan based on the acceptance of my students which I could reflect through their behaviour and mood. I need to mix and match which one is applicable based on my previous experiences to motivate and make them feel good in my less on." (Interview 2, Teacher 6, $1^{\text {st }}$ July 2019)

Some of the teachers reflected on their previous 
outcomes by concerning the strengths and weaknesses to prepare, to improve and to make changes in choosing the materials, approach to teach.

Sub-theme: Using suitable activities

"I a lways use the outcomes especially the strengths and weaknesses of the previous lesson to plan my new lesson. For example, if I'm teaching grammar my students will be sleepy if I just lecture them but if I do game and use visual they would capture what I teach easily. So, I have to use suitable activities to suit the topic and my students needs to let them put more efforts to involve in the activities I plan for them" (Interview 2, Teacher 4, $15^{\text {th }}$ July 2019).

Hence, reflection-for-action also helps them to develop their competency, integrity and purposes. The reflection process also enables them to manage their interdependence to solve the problems they have.

Sub-theme: Developing competency

"I always do some reading and study before I teach my students to reflect on what I should teach, how I have to teach them especially the new things which I need to highlight to them in the current topic taught" (Interview 2, Teacher $5,5^{\text {th }}$ July 2019).

Sub-theme: Developing integrity and purposes

"Normally, I have to refer on the syllabus to help me to plan my lesson. Based on the syllabus I have to consider a few important things to be included or excluded from my lesson with concern more on the suitability, sensitivity, context and the nature of the materials to be taught and to be learned" (Interview 2, Teacher 3, $25^{\text {th }}$ July 2019).

Sub-theme: Managing interdependence to solve problems

"Reflection before teaching gives me autonomy and freedom to look back, to look inwards and to look forward to solve and to avoid the same problem from occurring during the next lesson. So, reflecting on the characteristics of the learners lets me get ideas to create suitable teaching and learning activities to them." (Interview 2, Teacher 1, 29 ${ }^{\text {th }}$ July 2019).

\subsection{Theme Three: The Changes Made in Less on Planning during Reflection-for-Action Stage}

Based on the results gained in Phase three interview, it showed that, reflection-for-action was important for them to make changes especially in choosing suitable instructional strategies to prepare their lesson. They also put more concern to look back on the evidence and feedback before planning their teaching by analyzing, designing, developing materials, implementing new plan and maing evaluation again to continue improving their own teaching. The teachers transferred their reflection findings into their new lesson plans. For example, the teachers were reflecting and putting more concern to choose achievable learning objectives, to use correct focus skills, planning different activities, preparing different worksheets and materials for different abilities students to achieve the learning standard in their lesson plans.

Most of the activities planned were related to the learning objectives. Therefore, the activities they planned must be suitable for the students to encourage their active participation as well as to motivate themselves to learn. For the teachers, planning a good lesson also encouraged their students to digest the content delivered as the activities ranged from easy to difficult tasks based on Bloom's human cognition. Therefore, they could try out new ideas and create new materials to maximize their students learning potentials

Sub-theme: Applying special techniques and approaches to suit students' abilities.

"Mostly I had a positive assumption on my students. I always think that my students are willing to learn something new day by day. I knew my students well. Each of my students has different level of development and a few of my students are fully guided by me. I cope the differences of my students by applying a special technique and approaches to suit their abilities. I practice translation method to make my students clear and understand the content I delivered. Next, I always reflect on lesson require ment every time I write my lesson plan. It is a normal thing I do. KSSR syllabus is the guidance I use to plan my lesson. My aim to deliver my lesson is based on the KSSR content standards. I sometimes combined the content standard between KBSR and KSSR to make my lesson more effective and successful. Mostly, I use behavioris $m$ and constructivis $m$ theory to support my choice. I also pay attention to the context for learning. My attention goes to the students' backgrounds, interests, and needs. The clas sroom culture is the most important things in delivering my lesson." (Interview 3, Teacher 1, 25 ${ }^{\text {th }}$ August 2019).

Based on the findings, the researcher found that Participant 1 focused more her students, methods of teachings and the new curriculum, KSSR before she teaches the students. These elements lead to the achievements of the lesson objectives after the lesson took place.

Sub-theme: Applying theory in practice for a meaningful lesson

"I focus more on the lesson achievement. I hope my students are willing to achieve the lesson objectives. I knew my students well. I knew their different backgrounds and abilities. I cope the differences of my students by implementing different approaches and methods in my teaching and learning classroom. I plan my lesson based on the KSSR syllabus and modular approach requirement. I chose suitable methods to deliver my lesson in order to match my students' 
abilities and needs. Mostly, I use behaviorism and constructivis m theory and sometimes I use cognitivist as the school applied 21st century classroom. These learning theories helped me and the students to digest the content. I was very concerned about the learning context. I always make sure the classroom environment is comfortable for my students to receive the lesson. But I had a problem with the crowded classroom and mixed ability students in the classroom. I need to prepare 3 worksheets a day for remedial, enrichment and enhancement. Next, role as a teacher and role as students are the most important discipline elements in my class room culture. Although the students are spoon feed, good behavior and respect each other are the keys to stay calm and positive in my classroom." (Interview 3, Teacher 2, $10^{\text {th }}$ August 2019).

The researcher found that Participant 2 was very conservative as she really focused on the lesson objectives, lesson achievement and teaching methods and strategies to cope with different abilities students.

Sub-theme: Trying out new teaching strategies

"I practiced my teaching according to the students' abilities. I focused my teaching more on language skills as to equip the students with good basic language skills according to KSSR requirements. Pairing learning, group learning and individual learning were the most popular techniques chosen during the planning process. I chose the methods to make my lesson more enjoyable. It was because my previous lesson went well with those methods. I promoted active learning in my classroom by implementing behaviorism, cognitivist and constructivism activities such as lecture, drilling, group work and mind-mapping to suit the learning context." (Interview 3, Teacher 3, $19^{\text {th }}$ August 2019).

The findings showed that Participant Three, was caring and flexible. She learnt from her past classroom experiences to plan and deliver her lesson. The fun learning elements were implemented in her lesson. She cared of her students, language skills, syllabus, and new curriculum demands, teaching methods and achievement.

Meanwhile, Participant four, five and six used reflections before teaching to showed their responsibilities for their work and their students' capability, role as a teacher to be fair to their students and their capability to do the job.

Sub-theme: Maximizing the students' learning potential.

"I use same method which suits to all level of abilities as I put in the objectives, the students could answer at least 5 from 10 questions given correctly. 5 means for the weak students meanwhile 6 to 10 correct answers mean on average for good students." (Interview 3, Teacher 6, $14^{\text {th }}$ August 2019).

Sub-theme: Considering alternatives and flexibility

"I use different worksheets based on their abilities in my class. I use different approach to teach them as they are not the same; some are introverts, some are extroverts and some are ambiverts. I think it is fair." (Interview 3, Teacher 4, $20^{\text {th }}$ August 2019).

Sub-theme: Being responsible to build partnership "I use my previous experiences to know who they are in my class. So I could have a better partnership with them to help me to teach better. For me building a good relation with them make my teaching go s moothly. The ir trust and acceptance let them put themselves with me during the lesson." (Interview 3, Teacher 5, $11^{\text {th }}$ August 2019).

\subsection{Theme Four: The Extent of Teachers' Reflection-for-Action}

The six of them also strongly agreed that they used forward planning stage, central planning stage and backward planning stage to plan their lesson (see Appendix 2). The findings showed that, six of them were using the three stages of reflection to plan their lesson. They also prepared their lesson by including the needed elements such as learning objectives, skills to be taught as stated in the syllabus as showed in their les son plans.

Next, they also reflected on their students' works and readiness as to help them to decide on what to focus on a particular class of students, to look at a feature of their teaching, for example how they deal with incidents of misbehavior and how they encourage their students to speak more English in class. The teacher decided the suitable approach to be used in the particular lesson to match the lesson requirement and the context to be taught. The teachers referred to the syllabus and selected the methods before selecting the content to be taught. They also made a suitable teaching targets in backward planning stage based on forward planning and central planning.

Sub-theme: Reflecting on the methods and examples (forward planning and central planning stage)

"Mostly I select the suitable methods before selecting the content based on the syllabus, of course. It is important for me to use correct teaching strategies to teach the content. I also provide examples and variation of worksheets and activities for different abilities students in my class to help them understand the content I taught." (Interview 4, Teacher 5, $1^{\text {st }}$ September 2019).

Sub-theme: Reflecting on the syllabus to target the learning objectives (forward planning stage central planning stage and backward planning stage)

"Reflecting before planning is needed. I use it to identify the content of current lesson based on the syllabus, so that we are on track. Next, I select suitable approaches to match the requirements, by preparing materials, examples and concerning our abilities and capabilities." (Interview 4, Teacher 1, $2^{\text {nd }}$ September 2019). 
Sub-theme: Reflecting on the syllabus, methods and target lesson outcomes (forward planning stage central planning stage and backward planning stage)

"I plan my lesson by focusing more on learning process to achieve the lesson objectives. I'm implementing different approaches and methods in my classroom. I plan my lesson based on the syllabus requirements by adapting and adopting some information to match my students' abilities and needs to make sure the classroom environment is comfortable for them. I prepare different worksheets for remedial, enrich ment and enhancement." (Interview 4, Teacher 2, $21^{\text {st }}$ September 2019).

The findings also showed that, the teachers reflected on the lesson requirement and context to help them to know what to look for when they were planning their lesson. The teacher selects the methods before selecting the content to be taught. But two of the participants missed the examples and variation to select the methods for different abilities students. They agreed reflection was not a haphazard event. It was a planned event with certain thoughts in their mind. They claimed that, reflection before teaching was important for them to understand the goals and objectives of the lesson they were going to deliver which is related to [27].

Therefore, all of them decided on the target lesson outcomes, the learning objectives at first based on SMART approach (Specific, Measureable, Attainable, Realistic, and Time-bound) based on the lesson requirement. The teacher also decided on the instructional activities to be done in the classroom after deciding on the learning objectives based on the students' abilities and teacher's abilities. All of them provided the examples and variation of materials to help their students to understand the content taught during planning their lesson based on what they had learnt from their previous lessons.

They could develop a plan of action for a meaningful lesson outcome based on a good lesson plan [32]. The teachers were clear on what the introductory or engagement part of the lesson would be during the planning process. The participants also agreed the time they used to plan their lesson, gave them opportunity to think and reflect on their students especially about what the most effective learning behaviors suit their students and how they are going to decide what work is best for their students as suggested by [6].

In relation to that, reflection before teaching helped them to plan the activities to fulfill the students' multiple intelligence such as verbal interaction, hands-on manipulation, drawing, demonstration or working with a partner to deliver the lesson meaningfully which is similar to [2] who found that effective teachers teach the students based on what they could do but not on what they could not do.

Next, the teachers also agreed that they had a chance to think and understand their expectation from the students and to select the most suitable teaching behaviors which were necessary and suit their students well to motivate them to learn at their own pace which is in line with [35]. The findings were also related to [12], who described reflection as the "active, persistent, and careful consideration of any belief or supposed form of knowledge in light of the grounds that support." The teachers showed that they examined and experienced their own as sumptions of students, subject matter, learning theory and techniques, the context, and their core be liefs in order to learn and grow their teaching practice. This showed that experiential learning through reflecting on their experiences were beneficial to the teachers to learn and make changes in their practices. It also stimulated and encouraged them to be more positive and productive in teaching, which is related to [25]. This finding revealed that teachers used reflection-for-action to plan a betterEnglish lesson.

\section{Conclusions}

The results of this study provided an understanding of how reflection-for-action could help Eng lish language teachers to succeed in their teaching by encouraging them to make changes to use correct approaches, methods, examples and activities to suit the teachers' and students' ability and capability started from the planning stage until ending of the lesson. In regard to encourage students' participation in learning English language, the results also showed that the use of reflection-for-action in teaching makes the teachers more concerned about students' cognitive development which resulted from the application of reflective teaching in the classroom that created chances and opportunities for the students to learn the target language meaningfully. Hence, through reflection-for-action, the teachers in this study had more opportunities to succeed and to enhance the quality of their own teaching as reflection-for-action guided them to be more concerned, flexible, open and to think critically during lesson planning.

\section{Other Recommendations}

It is good to have further exploration of the implementation of reflection-for-action among in-service teachers from other subjects and contexts. We are very grateful to experts for their appropriate and constructive suggestions to improve this template.

\section{REFERENCES}

[1] M.H. Alanazi "A Study of the Pre-Service Trainee Teachers Problems in Designing Lesson Plans", Arab World English Journal, 10(1). pp. $166-182,2019$. 
[2] P. An, S., Bakker, S., Ordanovski, R., Tacon is, C.L., Paffen \& B., Eggen, B. "Unobtrusively Enhancing Reflection-in-Action of Teachers through Spatially Distributed Ambient Information" In Proceedings of the 2019 CHI Conference on Human Factors in Computing Systems, p. 91, 2019.

[3] O.W., Ann, S., Swanto \& A., AlSaqqaf "Pre-service ESL teachers engaging in Reflective Practice: Current Observations and Perceived Challenges" Journal of Research, Policy \& Practice of Teachers \& Teacher Education (JRPPTTE), 8(2). pp. 5-18, 2018.

[4] A., Asib \& S., Marmanto "In-Service EFL Teachers' experiences of Conducting Reflective Practice as Continuing Professional Development", International Journal of language Education (Ijole), 2(2). pp. 52-64, 2018.

[5] R., Bakar "The influence of professional teachers on Padang vocational school students' achievement", Kasetsart Journal of Social Sciences, 39(1), pp. 67-72, 2018.

[6] M., Buckingham \& D.O., Clifton, Now, Discover Your Strengths. New York: The Free Press, 2001.

[7] S. C., Choy, J. S. C., Yim \& P.L., Tan "Reflective thinking among preservice teachers: A Malaysian perspective". Issues in Educational Research, 27(2), pp. 234-249, 2017.

[8] A., Cirockia \& H. P., Widodo "Reflective Practice in English Language Teaching in Indonesia: Shared Practices from Two Teacher Educators". Iranian Journal of Language Teaching Research, 7(3), pp.15-35, 2019.

[9] I., Cornford "Reflective teaching: Empirical research findings and some implications for teacher education". Journal of Vocational Education and Training, 54(2), pp.219-235, 2002.

[10] N., Cull, A., Cai, D., Heemi \& D., Dokmanovic, "Care, hope and resistance: Reshaping teacher professional learning for inclusive education". International Studies in Widening Participation, 5(1), pp 21-36, 2018.

[11] S., Daneshfar \& M., Moharami, "Dynamic assessment in Vygotsky's sociocultural theory: origins and main concepts". Journal of Language Teaching and Research, 9(3), pp. 600-607, 2018.

[12] J., Dewey, How we think. A restatement of the relation of reflective thinking to the educative process. Boston: D.C. Heath, 1933.

[13] C., Dickerson, K., Thomas, J., Jarvis \& R., Levy, “Changing practice in Malaysian primary schools: learning from student teachers' reports of using action, reflection and modelling (ARM)." Journal of Education for Teaching, 44(2), pp. 194-211, 2018.

[14] T., El Masry, M., Saad \& M., Rashid, "On the Cultivation of Their Community of Practice: A Case Study of EFL Malaysian Pre-Service Teachers." The qualitative report, 23(4), pp. 952-977, 2018

[15] T.S., Farrell, Reflective Practice in Action: 80 Reflection Breaks for Busy Teachers. California: Corwin Press, 2004.

[16] T. S., Farrell, "Reflecting on ESL teacher expertise: a case study”. System, 41(4), pp. 1070-1082, 2013.
[17] L., Foong, M.B.M., Nor \& A., Nolan, "Individual and collective reflection: Deepening early childhood pre-service teachers' reflective thinking during practicum." Australasian Journal of Early Childhood, 43(1), pp. 43-52, 2018.

[18] M., Hassanzadeh, F., Marefat \& A., Ramezani, "The impact of single versus multiple recasts on L2 learners' implicit and explicit knowledge.” Heliyon, 5(5), p. e01748, 2019.

[19] M., Hanafi, "Perceptions of reflection on a pre-service primary teacher education programme in teaching English as a second language in an institute of teacher education in Malaysia," Doctoral dissertation, Canterbury Christ Church University, 2019.

[20] B.P., Hung, "Meaningful learning and its implications for language education in Vietnam. Journal of Lan guage and Education," 5(1), pp.98-102, 2019.

[21] D., Kay \& J., Kibble, "Learning theories 101: application to everyday teaching and scholarship". Advances in phy siology education, 40(1), pp. 17-25, 2016.

[22] M.K., Khalil \& A., Elkhider, "Applying learning theories and instructional design models for effective instruction". Advances in physiology education, 40(2), pp. 147-156, 2016.

[23] J. Killion \& G. Todnem, "A process for personal theory building. Educational Leadership,” 48(6), pp. 14-16, 1991.

[24] L.K. Kor, S. F., Tan \& C.S. Lim, “Capturing Changes and Differences in Teacher Reflection through Lesson Study: A Comparison of Two Culturally Diverse Malaysian Primary Schools." In Theory and Practice of Lesson Study in Mathematics. pp. 369-391, 2019.

[25] I. Lee, "Future directions for writing teacher cognition." The TESOL ency clopedia of En glish lan guage teaching, pp. 1-7, 2018.

[26] C.V. Madin \& S. Swanto, "An Inquiry Approach to Facilitate Reflection in Action Research for ESL Pre-Service Teachers." TEFLIN Journal, 30(1), pp.1-21, 2019.

[27] L. Mandouit, "Using student feedback to improve teaching." Educational Action Research, 26(5), pp. 755-769, 2018.

[28] P. Mathew, P., Mathew \& P., Peechattu, "Reflective practices: A means to teacher development." Asia Pacific Journal of Contemporary Education and Communication Technology (APJCECT), 3(1), pp. 126-131, 2017.

[29] P. Miller \& I. Potter, "Teacher CPD across borders: Reflections on how a study tour to England helped to change the practice and praxis among Jamaican teachers." International Journal of Education and Practice, 2(1), pp. 9-20, 2014

[30] W.Y. Min, R. Mansor \& S. Samsudin, "Facilitating Reflective Practice in Teacher Education: An Analysis of Student Teachers' Level of Reflection during Teacher Experience." International Journal of Academic Research in Business and Social Sciences, 7(3), pp. 599-612, 2017.

[31] D.E. Murray \& M. Christison, What English language teachers need to know volume I, Understanding learning, London, Routledge, 2019. 
[32] M.B. Nathenson \& E.S. Henderson, Using student feedback to improve learning materials, London, Routledge, 2018.

[33] M. Nind \& S. Lewthwaite, "Methods that teach: developing pedagogic research methods, developing pedagogy." International Journal of Research \& Method in Education, 41(4), pp. 398-410, 2018.

[34] C. Ng, "Using student voice to promote reading en gagement for economically disadvantaged students." Journal of Research in Reading, 41(4), pp. 700-715, 2018.

[35] R.L. Pecheone \& A. Whittaker, "Well-prepared teachers inspire student learning." Phi Delta Kappan, 97(7), pp. 8-13, 2016.

[36] N.T. Quezada, M. J. I., Araos \& M. Rosas-Maldonado, "Points of Improvement: Reflective Strategy to Support Chilean EFL Pre-Service Teachers' Lesson Planning." HOW Journal, 26(2), pp. 88-105, 2019.

[37] D.A. Schön, The reflective practitioner: how professionals think in action. Aldershot, England, Ashgate, 1983.

[38] X.Y. Shu, "Learning How to Teach English in Elementary School: The Role of Reflective Teaching in Training Elementary School Teachers." Open Access Library Journal, 4. pp.e3496, 2017.

[39] L. Tajik, S. A., Mirhosseini \& A. Ramezani, "Now as a Teacher: Novice Teachers Reflect on English Language Teacher Education in Iran." The Qualitative Report, 24(6), pp. 1373-1398, 2019.

[40] T. Tosriadi, A., Asib, S., Marmanto \& U. A., Azizah, "Peer observation as a means to develop teachers' professionalism.” International Journal of Multicultural and Multireligious Understanding, 5(3), pp. 151-158, 2018.

[41] T. Tosriadi, A., Asib, S., Marmanto \& U.A., Azizah, "In-Service EFL Teachers' reflection as a Pathway to Develop Professionalism." International Online Journal of Education and Teaching, 5(4), pp.921-932, 2018.

[42] J. Yin, "Empowering teachers through core reflection: A case in Korea.” Journal of Asia TEFL, 15(4), p. 1005, 2018. 